\title{
OPTIMALISASI BANK SYARI'AH MENUJU GOOD CORPORATE GOVERNANCE
}

\author{
Fahrur Ulum \\ (Penulis adalah dosen pada Fakultas Syari'ah IA IN Sunan A mpel Surabaya \\ sekaligus mahasiswa S3 IA IN Sunan A mpel Surabaya)
}

\begin{abstract}
A bstract:
Syarî'ah banking must be optimized earnestly to fulfill the stakeholders interest. The effective implementation of cooporate governance would realize the goal of fairness, accountability, and transparancy. There are several prior focus of this system manager: basic concept and problems of cooperate governance in syarî'ah banking, the pillars of implementation, and the mechanism. As a result, to create an effective cooperate governance of syariah banking, the following aspects must be urgently required: a contract darity, market discipline, moral dimension, socio-political atmosphere, law enforcement, and institution. Board of directors, senior management, stockholders, and depositors have important roles to establish the harmony of syariah banking development. The stakeholders are directly connected to the mechanism of cooperate governance of syariah banking.
\end{abstract}

\section{Key Words:}

corporate governance, bank syari'ah, stakeholders, dan mudlârabah

\section{Pendahuluan}

Secara fakta, meskipun bank syari'ah masih memiliki cakupan yang relatif kecil, namun selama ini menunjukkan perkembangan yang menggembirakan. Tulisan ini muncul sebagai refleksi dari kebanggaan atas berkembangnya bank syari'ah sekaligus keprihatinan operasionalnya yang masih menekankan pada produk dengan sistem jual beli seperti murâbahah, istisna' dan salâm. Masih sedikit sekali yang menggunakan akad penyertaan, seperti mudlârabah 
Fahrur Ulum

dan musyârakah. Padahal akad penyertaan tersebut yang seharusnya merupakan core product dari sistem keuangan Islam. ${ }^{1}$

Selanjutnya, untuk mencapai pengembangan dan ekspansi bank syari'ah di masa yang akan datang dibutuhkan kemampuan dan kapabilitas para pelaku sistem. Jika bank syari'ah mampu membangkitkan kepercayaan nasabah, maka ia akan mampu memobilisasi dana, meningkatkan investasi, menciptakan lapangan kerja, membantu keuangan pemerintah dalam mengatasi defisit anggaran dan mempercepat pertumbuhan ekonomi.2 Untuk memastikan tercapainya tujuan-tujuan tersebut serta menciptakan kesehatan dan stabilitas keuangan, maka peningkatan corporate governance merupakan syarat mutlak yang harus dipenuhi oleh perbankan syari'ah.

Wilayah operasi bank syari'ah pada saat ini pada komunitas yang relatif besar. Pertanyaan yang penting adalah bagaimana membentuk rasa saling percaya di antara para stakeholder (pemegang saham, deposan, direktur, managemen dan pengguna dana). Jika hal itu tidak tejadi, bukan tidak mungkin perbankan syari'ah akan mampu melanjutkan perkembangannya untuk memeperoleh posisi yang penting di negara-negara muslim. Seandainya bisa terealisasi, operasionalnya akan menggantungkan pada prinsip jual beli, dan hal ini belum mencerminkan karakteristik sistem keuangan Islam. Oleh karena itu, penting untuk menciptakan lingkungan yang sesuai dengan zaman modern dalam rangka membantu meminimalkan resiko ${ }^{3}$ dan menciptakan iklim saling percaya di antara stakeholder.

Salah satu pilar penting yang harus diciptakan untuk mengganti sosio-ekonomi yang lama adalah corporate governance yang efektif pada bank dan nasabah pengguna dana. Namun corporate governance justru sering menjadi unsur kelemahan pada perusahaan-

\footnotetext{
IUmer Chapra dan Habib Ahmed, Corporate Governance Lembaga Keuangan Syari'ah (Jakarta: Bumi A ksara, 2008), hlm. 2.

2l bid., hlm. 3.

3Resiko selalu ada dalam semua sistem keuangan, meliputi fiduciary mon ey, fluktuasi suku bunga, piutang yang gagal dibayar, kesalahan operasional, bencana alam, dan kesalahan karena faktor manusia. Pada perbankan syari'ah, resiko tersebut harus ditambah lagi dengan resiko karena penerapan sistem profit and loss sharing. Dan inilah keunaikan dari sistem keuangan Islam. Lebih lengkap bisa lihat Umer Chapra, CorporateG overnance, hlm. 9.
} 
perusahaan di sejumlah negara berkembang. ${ }^{4} \mathrm{Hal}$ ini karena semua institusi yang seharusnya berperan penting dalam mengawasi dan menjamin efisiensi dan integritas pasar justru tidak berfungsi dengan baik. Masih terdapat kesenjangan informasi yang sangat mencolok, para pelaku pasar kurang berpengalaman, undang-undang belum mampu mengatur dengan efektif karena mental korup dan sejumlah kelemahan sistem peradilan. Konsep transparansi belum diterapkan dengan baik, begitu juga dengan praktek akuntansi yang belum berkembang secara optimal. 5

Karena urgensitas corporate governance tersebut, perbankan Islam harus bisa meningkatkan kinerjanya secara sungguh-sungguh dan memenuhi kepentingan para stakeholder dengan menerapkan corporate governance secara efektif. Dasar pemikiran yang kuat akan keadilan sistem ekonomi Islam patut dijadikan sebagai landasan untuk mengadopsi semua ukuran yang memungkinkan berfungsinya sistem keuangan dalam menjaga kepentingan seluruh stakeholder.

Tanpa penerapan corporate governance yang efektif, bank syari'ah akan sulit untuk bisa memperkuat posisi, memperluas jaringan, dan menunjukkan kinerjanya dengan lebih efektif, apalagi seiring dengan makin kompleksnya masalah yang dihadapi oleh perbankan syari'ah. Oleh karena itu, perlu upaya pengembangan corporate governance pada perbankan syari'ah untuk meningkatkan pertumbuhan dan pengakuan dunia internasional, selain untuk melindungi semua kepentingan stakeholder.

\section{Konsep D asar G ood Corporate G overnance}

Corporate governance adalah serangkaian hubungan antara manajemen perusahaan, pengurus, pemegang saham, dan semua pihak yang berkepentingan terhadap perusahaan (stakeholder). 6 Pada perbankan syari'ah, stakeholder lebih banyak daripada perbankan konvensional, ini menjadi permasalahan tersendiri yang harus

4Schleifer dan Viahny, “A Survey of Corporate Governance”, Journal of Finance, Juni1997), hlm. 737-783.

5Stephen Prowse, "Corporate Governance: Emerging Issues and Lesson for East A sia": www.worldbank.org (diakses pada 18 N ovember 2010).

William R. White, "Fixing Finance": www.oecd.org (diakses pada 21 November 2010). 
Fahrur Ulum

diantisipasi. Demikian juga adanya pola interaksi yang berbeda. Oleh karena itu, perlu menentukan format yang lebih jelas dalam pembahasan corporate governance dalam perbankan syari'ah.

Hingga saat ini, model corporate governance terbagi menjadi dua aliran. Pertama model Anglo-A merican dan kedua model FrancoGerman. Model corporate governance Anglo-American lebih memfokuskan pada cara memaksimalkan kepentingan pemegang saham. Menurut model ini, jika terjadi konflik kepentingan antara pemegang saham dengan pihak lain, maka yang harus dimenangkan adalah kepentingan pemegang saham. ${ }^{7}$ Sementara itu model FrancoGerman menempatkan seluruh stakeholder pada posisi yang sama sehingga secara teori, kepentingan semua stakeholder harus dilindungi.

Dikotomi teori yang berimplikasi pada jaminan kepentingan stakeholder tersebut menimbulkan pertanyaan pada lembaga kauangan syari'ah, apakah sistem Islam dengan segala nilainya mampu melindungi hak seluruh stakeholder, terlepas apakah mereka mempunyai penyertaan modal atau tidak. Mestinya, secara teoritis nilai Islam yang menjunjung tinggi nilai-nilai keadilan pasti bisa memberikan perlindungan kepentingan pada semua stakeholder, namun kenyataan di lapangan masih menunjukkan adanya ketidaksempurnaan penerapannya. Oleh karena itu, upaya penerapan pekerjaan yang mengarah pada kesempurnaan perlindungan secara adil bagi semua stakeholder harus terus diupayakan.

Bagi dunia perbankan syari'ah, jika mereka tidak mampu menunjukkan kinerja yang baik, maka orang akan beranggapan bahwa sistem Islam tidak selaras dengan dunia modern dan Islam akan disalahkan atas hal hal yang terjadi tersebut. Dalam sistem perbankan Islam, kepentingan pemegang saham harus diperhatikan. Namun lebih jauh dari itu, para deposan juga harus dianggap sebagai bagian dari stakeholder dan mendapat perhatian utama. Inilah yang membedakan dengan sistem perbankan konvensional yang menganggap bahwa deposan bukan bagian dari stakeholder. Hal ini dikarenakan dalam perbankan konvensional, semua jenis simpanan telah dijamin asuransi dan suku bunganya telah diketahui di awal.

7Macey dan O'hara, "The Corporate Governance of Bank": irm29@cornell.edu (diakses $22 \mathrm{~N}$ ovember 2010). 
Ketika investasi deposan dalam sistem perbankan Islam telah menggunakan prinsip profit and loss sharing, maka kepentingan mereka telah dilindungi. Demikian juga para pegawai termasuk stakeholder, karena kontribusi terhadap efektifnya kinerja bank dan gaji mereka ditentutkan oleh struktur insentif bank. Sistem keuangan juga bagian dari stakeholder karena kegagalan dari mayoritas bank akan menyebabkan krisis dan mengancam perekonomian secara umum. Kepentingan pemerintah juga bagian dari stakeholder karena kinerja bank juga dapat memberikan keuntungan bagi pemerintah. $\mathrm{Hal}$ ini yang mendorong pemerintah untuk memaksa otoritas pengawas dan regulator agar melaksanakan tugasnya secara konsisten.

Dalam sistem perbankan syari'ah, tantangan untuk menciptakan keadilan pada semua stakeholder sangat urgen. Hal ini karena dalam sistem perbankan konvensional masih sering terdapat konflik kepentingan antara pemegang saham dengan pihak managemen. Pada perbankan syari'ah, salah satu pihak yang perlu mendapat perhatian adalah nasabah, karena sebagaimana para pemegang saham, para nasabah juga telah berkontribusi dalam menghimpun dana.

Kompetisi dalam kerangka kerja teori ekonomi akan berlangsung untuk jangka waktu yang panjang sehingga dapat membentuk keseimbangan yang akan memuaskan kepentingan semua stakeholder secara optimal.8 Pengalaman menunjukkan bahwa ketergantungan terhadap mekanisme pasar untuk menjamin efektifitas corporate governance merupakan hal yang tidak realistis. ${ }^{9}$ $\mathrm{Hal}$ ini cukup beralasan, karena investasi yang dilakukan tidak bisa secara simultan bertukar dengan barang tangible. Yang ada hanya janji dari ketidakjelasan return di masa yang akan datang dan investasi harus meyakini akan terpenuhinya janji tersebut. Alasan lainnya adalah tidak ada seorangpun yang bisa sabar untuk menunggu dalam jangka waktu yang panjang. ${ }^{10}$

8 Armen A Ichian, "Uncertainty, Evolution and Economic Theory", Journal of Political E conomy, edisi 58 (1950), hlm. 211-121.

9Schleifer, A Survey of CorporateG overnance, hlm. 738.

10Dalam hal ini Keynes seperti yang dikutip dalam Collected W riting berpendapat bahwa "dalam jangka panjang, kita semua akan mati". Lihat John Maynard Keynes, 
Fahrur Ulum

Dapat dipahami bahwa permasalahan dasar dalam corporate governance yaitu berkaitan dengan pemenuhan janji kepada para investor dan nasabah. ${ }^{11}$ Sebenarnya permasalahan ini bisa terjadi pada semua perusahaan, namun akan lebih kompleks jika terjadi pada bank, karena bank lebih banyak menggunakan leverage dan menghadapi resiko sistemik.12 Permaslahan seperti ini juga bisa terjadi pada perbankan syari'ah, misalnya pada akad mudlârabah, di mana mudlârîb (bank) menggunakan dana dari shâhib al-mâl (nasabah). Antara keduanya saling membutuhkan, di mana pengusaha membutuhkan modal dan pemilik modal membutuhkan pengusaha yang mempunyai keahlian dan tenaga. Bagaimanapun, dalam kondisi saling ketergantungan seperti ini konflik kepentingan akan muncul. Bagi pengusaha ada banyak cara illegal yang dapat mengurangi bagian laba dari pemilik modal. Sedangkan pemilik modal menghendaki bagian profit sebanyak mungkin. Jika hubungan di antara keduanya dapat dibangun atas dasar kejujuran dan keadilan, maka keseimbangan dapat diwujudkan dan akhirnya akan memberikan keuntungan bagi keduanya dan bagi perekonomian secara luas. Penerapan corporate governance yang efektif sangat dibutuhkan untuk mengembangkan sistem keuangan Islam, tujuannya adalah untuk memenuhi kepentingan semua stakeholder secara adil.

\section{Aspek Utama Penerapan Corporate G overnance}

Aspek utama penerapan corporate governance pada perbankan syari'ah, antara lain, adalah kejelasan dalam kontrak, disiplin pasar, dimensi moral, lingkungan sosio-politik, serta penegakan hukum dan kelembagaan.

Salah satu kontrak yang komprehensif dalam perbankan syari'ah adalah kontrak mudlârabah. Hanya saja kontrak ini tidak feasible, bahkan tidak diinginkan. Dikatakan tidak feasible karena

Collected W ritings of John M aynard Keynes (London: MacMillan for the Royal Economic Society, 1972), hlm. 85.

11Alexander Dyck, "Ownership Structure, Legal Protections and Corporate Governance": sdyck@hbs.edu (diakses 22 N ovember 2010).

12 Chapra, Corporate Governanc, hlm. 27. 
membutuhkan pengetahuan yang sempurna terhadap kondisi pasar dan kemungkinan-kemungkinan yang akan terjadi terhadap kedua belah pihak (shâhib al-mâl dan mudlârib). Oleh karena itu penting untuk memperhatikan agency cost agar memenuhi dan menjaga kepentingan kedua belah pihak.

Jansen dan Meckling, telah merinci agency cost ini menjadi tiga unsur, yakni:13 (1) Biaya pengawasan oleh pemilik modal (principal) untuk mengawasi bisnis yang dijalankan oleh mudlârib (agent); (2) biaya pengikatan untuk memastikan pemilik modal bahwa mudlârib tidak akan melakukan sesuatu yang dapat merusak kepentingan pemilik modal dan akan mengganti kerugiannya jika hal itu benarbenar terjadi; dan (3) residual loss atau sisa kerugian yang harus ditanggung oleh pemilik modal akibat keputusan mudlârib yang menyimpang dari keputusan yang dibuat oleh pemilik modal ketika ia mempunyai informasi dan kemampuan yang sama dengan mudlârib. Poin satu dan dua adalah pengeluaran di luar anggaran, sedangkan poin tiga adalah pengeluaran yang riil, meskipun hal itu sulit untuk diukur.

Pada aspek kedua, yaitu disiplin pasar, maka hal itu merupakan faktor yang sangat penting dalam meningkatkan reputasi lembaga. Hal itu sudah terbukti sejak masa lalu hingga saat ini untuk memepertahankan dan meningkatkan share value dari pemegang saham dan deposan serta memungkinkan bank untuk melakukan ekspansi. Ekspansi akan menciptakan skala ekonomi, dan pada gilirannya akan dapat mengurangi biaya dan meningkatkan laba. Selain itu, dewan direksi dan manajemen juga akan mendapatkan tingkat remunerasi yang lebih baik.14

Disiplin pasar akan menjadi tidak efektif jika pihak bank membuat laporan keuangan seperti neraca dan laporan rugi laba yang tidak merefleksikan kondisi yang sebenarnya. Demikian juga para pengguna dana juga berada pada posisi yang sama, jika ia tidak melaporkan laba yang diterimanya dengan jujur dan terbuka kepada pihak bank.

13Jenson dan Meckling, "Theory of Firm: Managerial Behavior, Agency Cost and Ownership Structure", J ou rnal of Financial E conomics, edisi 3, (1976), hlm. 305-360.

${ }^{14}$ Chapra, Corporate G ov ernance, hlm. 30. 
Fahrur Ulum

Disiplin pasar akan bisa berjalan lebih efektif dengan sejumlah dukungan. Salah satunya adalah dukungan moral dari para pelaku pasar. Roepke menyatakan bahwa disiplin pribadi, keadilan, kejujuran, kebaikan, semangat kebersamaan, peduli pada masalah kemanusiaan dan etika usaha merupakan hal-hal yang harus dipenuhi oleh seseorang sebelum terjun ke pasar dan berkompetisi antara satu sama lain. Inilah dukungan yang sangat dibutuhkan untuk mencegah menurunnya semangat kompetisi dan kejujuran.15

Oleh karena itu, tidak cukup hanya mengharap kepada hukum pasar, tetapi membutuhkan dukungan dari nilai-nilai moral yang tinggi. Nilai-nilai ini dapat mendorong terciptanya kesepakatan dan komitmen dalam kontrak. Bank harus menunjukkan itikad baik dalam operasionalnya untuk memenuhi kepentingan semua stakeholder. Segala bentuk pelanggaran dari prinsip kejujuran dan ketidakadilan, baik yang dilakukan oleh pihak bank maupun nasabah adalah termasuk pelanggaran terhadap prinsip-prinsip Islam.

Agar nilai-nilai moral bisa efektif dijalankan, setidaknya ada dua syarat sehingga bisa berperan penting dalam mempengaruhi pasar, yaitu: Pertama, adanya motivasi yang kuat dan kesadaran pribadi dari semua pihak untuk menerapkan nilai-nilai ini dalam sistem. Kedua, adanya dukungan sistem yang memberikan insentif dan pencegahan. Dalam sistem sekular, tidak dikenal balasan dan hukuman di akhirat yang mampu menjamin mereka untuk berbuat baik dan menjunjung nilai-nilai yang tinggi dalam berbisnis. Sedangkan bagi umat Islam mengenal adanya balasan akhirat, namun tetap saja tidak menjamin bagi mereka untuk menjunjung tinggi nilainilai luhur. Oleh karena itu agar mereka selalu mengerjakan yang baik dan meninggalkan yang buruk, diperlukan sistem reward dan punishment.

Aspek penerapan corporate governance yang berikutnya adalah pembentukan lingkungan yang kondusif, baik secara sosio-ekonomi, politik, hukum maupun kelembagaaan. Namun sayang sekali, ketaatan pada norma-norma Islam dalam perilaku masyarakat tidak selalu sesuai dengan yang diharapkan. Survey yang dilakukan oleh Umar Chapra yang berkaitan dengan pengaruh praktik korupsi

15Wilhelm Roepke, "Ordred Anarchy", dalam Lawrence Stepplevich, The C apitalist Reader (N ew York: New RochelleA rlington, 1977), hlm. 60. 
dalam transaksi bisnis, menunjukkan adanya perbedaan opini, di mana separuh dari responden mengatakan bahwa lingkungan moral (ethical overlay) baik sekali, sepertiganya mengatakan kurang, dan sisanya mengatakan cukup. Perbedaan opini tentang lingkungan moral ini bisa dipertemukan ketika dalam kenyataannya mereka yang mengatakan baik sekali berada pada negara-negara di mana regulasi dan pengawasan sudah berjalan efektif. ${ }^{16}$

Kemerosotan sosial ekonomi, politik dan moral yang terjadi pada negara-negara muslim membawa konsekwensi pada lemahnya pendidikan dan kontrol sosial. Inilah yang menjadi faktor utama terjadinya pelanggaran norma-norma Islam. Oleh karena itu, perlu upaya yang serius bagi terbentuknya sebuah lingkungan moral.17 Ketika para pelanggar norma-norma Islam ini masih berkeliaran di masyarakat dan mereka masih bisa hidup bermewah-mewahan, maka sarana pendidikan dan solidaritas umat harus digunakan untuk meningkatkan kesadaran moral individu maupun masyarakat agar tidak melanggar nilai-nilai moral Islam. Tanpa solidaritas sosial, penegakan nilai-nilai moral dan hukum tidak akan pernah berjalan efektif.

Selanjutnya, salah satu institusi yang paling penting dalam corporate governance adalah adanya perlindungan hukum bagi para stakeholder. Negara yang memberikan perlindungan terhadap investor pada umumnya memiliki perkembangan pasar keuangan yang baik dengan tingkat pertumbuhan yang tinggi, hingga pada gilirannya bisa mengurangi potensi terjadinya krisis. ${ }^{18}$ Jika perlindungan berjalan efektif maka akan menarik minat para investor untuk menginvestasikan dananya, baik di sektor perbankan maupun dalam badan usaha.

Ada hubungan linier antara perilaku masyarakat dengan lembaga hukum. Konsistensi antara norma moral dan sosial dengan perilaku yang berkembang di masyarakat merupakan keniscayaan dan akan menjadi modal sosial. Tanpa adanya modal ini, biaya untuk melakukan reformasi hukum akan terasa mahal.

16Chapra, Corporate G overnance, hIm 35.

17Pembahasan yang lebih lengkap berkaitan dengan hal ini silahkan baca Umar Chapra, The Causes of M uslim D ecline, (Jeddah: The Islamic Foundation, 2008), 173-252. ${ }^{18}$ La Porta, Lopez de Salinas, A Shleifer and R.W. Vinshy, Investor Protection; O rigins, Consequen ces, R eform, ( Harvard University, Manuscript: 2000), hIm 54. 
Fahrur Ulum

Reformasi moral di negara-negara muslim membutuhkan waktu yang cukup lama. Namun demikian, kekosongan kontrol kelembagaan tersebut tidak boleh dibiarkan berlarut-larut..19 Berkaitan dengan hal ini, maka pemerintah harus mempunyai perhatian khusus dalam rangka meningkatkan moral masyarakat dan aparat pemerintah itu sendiri. Ibn Khaldun berpendapat bahwa etika moral yang berasal dari syari'ah, tidak akan bisa direfleksikan dalam undang-undang, dan sebaliknya undang-undang tidak akan bisa diimplementasikan secara efektif jika pemerintah tidak memiliki perhatian terhadap tugas ini secara serius. 20

Hal lain yang perlu diperhatikan adalah pemenuhan perjanjian dalam kontrak dan hak-hak kepemilikan, karena menanamkan aspek tersebut dalam masyarakat merupakan keharusan bagi pembangunan kehidupan sosial yang berkeadilan. Douglas North menyebutkan bahwa pembangunan ekonomi hanya bisa dicapai dengan melakukan pengecekan atas prilaku yang menyimpang.21

\section{M ekanisme Good Corporate G overnance Bank Syarî'ah}

Untuk menciptakan good corporate governance, maka mekanisme yang ada pada stakeholder harus berjalan dengan baik. Pihak-pihak yang terkait langsung dengan mekanisme corporate governance bank syari'ah adalah: Pertama, dewan direksi. Dewan direksi harus mampu merumuskan strategi agar bisnis dapat berjalan secara efektif dan efisien sejalan dengan turbulensi kondisi inrternal dan eksternal. Oleh karena itu dewan direksi harus memiliki reputasi moral yang baik dan kompetensi teknis yang mendukung.

Untuk memilih anggota dewan direksi diperlukan standar profesionalisme tertentu, yaitu sebuah standar yang akan menentukan layak tidaknya seseorang untuk menjadi anggota dewan

19Survey yang dilakukan oleh Umar Chapra dan Habib A hmad menunjukkan bahwa hanya $36 \%$ dari responden yang menilai prosedur hukum sudah baik, $43 \%$ menilai cukup, $21 \%$ menilai kurang. Lihat Chapra, C orporate G overnance, hlm 39.

20lbn Khaldun, M u qaddimah (Kairo: al-Maktabah al-Tijâriyyah al-Kubra, tt.), hlm. 190191.

21Douglas North dan Barry Wiengsat, "Chapter Ideology and The Free Rider, The Evolution of Institution Geverning Public Choice in the 17th Century England", Journal of Economic History, Vol. 49 (1989), hlm. 832. 
direksi. Dalam konteks perbankan syari'ah, anggota dewan direksi dipersyaratkan memiliki kualifikasi tambahan, yaitu pemahaman atas al-maqâsid al-syarî'ah sebagai sebuah tuntunan Islam yang relevan dengan kegiatan bisnis dan keuangan.22

Dalam menjalankan tugasnya, dewan direksi harus intens melakuakn diskusi regular dengan para senior manajemen dan internal audit, menyusun dan menetapkan kebijakan, serta melakukan monitoring atas progresifitas pencapaian tujuan dan target perusahaan. Dewan direksi juga mempunyai kewajiban untuk menjaga transparansi dalam menjalankan operasional perusahaan yang mengacu pada standar operasional perbankan yang telah ditentukan oleh Basel Committee on Banking Supervision (BCBS), Accounting and Auditing Organization for Islamic Financial Institutions (AAOIFI), Islamic Financial Service Board (IFSB), ataupun otoritas pengawas.23

Kenyataannya, banyak direksi yang tidak mampu menjalankan aturan dan tugasnya secara efektif.24 Ada beberapa alasan yang menyebabkannya. Antara lain, pertama, dewan pengurus tidak selamanya memiliki profesionalitas dan kompetensi terhadap tugasnya. Kedua, dewan pengurus tidak memiliki integritas moral yang sangat diperlukan untuk menegelola sebuah bank. Ketiga, tidak selamanya dewan pengurus dipilih secara langsung dan murni oleh para pemegang saham dengan berbagai pertimbangan. Pemilihan juga tidak dilakukan secara regular, hal ini menunjukkan bahwa para pemegang saham tidak memiliki pengaruh aktif dan siknifikan dalam pemilihan ataupun pergantian dewan direksi.25

Dalam rangka meningkatkan efisiensi, dewan direksi hendaknya memiliki beberapa direktur eksekutif dan direktur noneksekutif. Direktur eksekutif memiliki tanggung jawab terhadap manajemen dan berusaha mencapai efisiensi sesuai dengan pengetahuan mereka terhadap potensi pasar dan bagian-bagian perusahaan. Sementara itu, direktur non-eksekutif setidaknya

${ }_{22}$ Chapra, Corporate Governance, hlm. 42.

23lbid., hlm. 43.

24Myles Mace, Directors: M yth and Reality (Boston: Harvard Business School Press, 1986), hlm. 57.

25David Prentice, "Some Aspect of Corporate Governance Debate", dalam Contemporary Issues in CorporateG overnance (Oxford: Clarendon Press, 2001), hlm. 31. 
F ahrur Ulum

memiliki vested-interest untuk menjaga dan mengembangkan kinerja manajemen, walaupun sebenarnya mereka tidak memiliki tanggung jawab tersebut. Selanjutnya, untuk meningkatkan optimalisasi dewan direksi perlu pula dilakukan penerapan sistem remunerasi anggota dewan direksi.26 Dewan direksi juga harus diantisipasi agar mereka tidak menerima secret profit untuk kepentingan pribadi. Karena itu moral para anggota dewan direksi menjadi prioritas utama.

Kedua, senior management. Senior management adalah CEO dan anggota senior lainnya yang menjalankan fungsi manajemen, dan ia tidak harus pemegang saham. ${ }^{27}$ Perusahaan modern biasanya tidak dikelola secara langsung oleh pemiliknya, namun di-hire oleh orang lain yang professional. Mereka itulah yang sering disebut sebagai fiduciaries.28

Senior management harus memastikan bahwa audit intrernal berjalan sesuai dengan prosedur. Selain itu dalam kompleksitas bank, harus diyakinkan bahwa tidak ada ambigu antara tugas dan wewenang CEO serta dewan direksi. Manajemen harus meyakinkan pula bahwa adanya independensi serta keseimbangan wewenang dan kekuasaan.

Segala aturan yang telah ditetapkan oleh manajemen akan berjalan secara efektif jika manajemen mampu menciptakan kualitas manajemen yang baik. Umar Chapra mengutip The Economist tentang tiga prinsip untuk menciptakan kualitas manajemen, antara lain kejujuran (honesty), cermat dan efisien (frugalitas), dan siap siaga (preparedness).29

\footnotetext{
26Dalam system perbankan syari'ah, penerapan metode ini terutama pada akad mudlârabah, anggota dewan direksi dalam kapasitas mereka sebagai mudlârib hanya akan diberi kompensasi terhadap pengeluaran yang riil atau actual expense. Remunerasi yang mereka dapatkan tidak secara periodik seperti pada perbankan modern, namun remun yang mereka dapatkan dalam bentuk persentase nisbah atas keuntungan yang didapatkan oleh pihak bank.

${ }^{27}$ Chapra, Corporate G overnance, hlm. 52.

28Fiduciaries adalah orang yang dipercaya untuk mewakili orang lain untuk suatu tujuan tertentu atau untuk melayani seseorang. Penjelasan selengkapnya lihat Katsuhito Iwai, "The Corporate Personal ity Controversy and Comparative Corporate Governance", dalam F. Cafaggi, A. N icita dan V. Pagano, Legal O rderings an E E conomic Institutions (London: Routledge, 2001), hlm. 104-105.

${ }^{29}$ Chapra, Corporate G overnance, hlm. 55.
} 
Beberapa ketentuan lain agar tercipta fungsi manajemen yang optimal dalam perusahaan, antara lain adalah perilaku hemat para pejabat dan pegawainya. ${ }^{30}$ Para fungsionaris bank tidak dibiasakan untuk hidup boros hingga membiasakan diri berhutang hanya untuk memenuhi keinginan yang sebenarnya tidak mereka butuhkan.

Ketiga, pemegang saham dan deposan. Para pemegang saham dan deposan perlu dibahas menyatu dengan pembahasan direksi dan manajemen dalam koridor perbankan syari'ah. Karakter perbankan syari'ah jelas berbeda dengan perbankan konvensional. Dalam perbankan konvensional, return sudah ditetapkan secara pasti (fixed and predetermined return). Namun dalam perbankan syari'ah mekanismenya berbeda. Deposan yang melakukan investasi di bank syari'ah akan memiliki partisipasi dalam hal keuntungan atau kerugian layaknya para pemegang saham. Namun mereka tidak memiliki hak suara dalam RUPS, walau mungkin nilai deposito yang diinvestasikan melebihi modal yang disetor oleh pemegang saham. Jika mereka diberikan jaminan return maka tentu bertentangan dengan spirit bank syari'ah.

Di sisi yang lain, bagi deposan giro, tentunya tidak secara langsung terkait dengan resiko bank. Hal ini karena sistem asuransi simpanan tidak memberi asuransi atas rekening giro yang jumlahnya melebihi limit yang ditentukan. Selanjutnya kerugian bank yang diakibatkan oleh bank dengan mekanisme PLS secara substansial sangat besar dan bahkan modal cadangan dana dan jenis simpanan lainnya tidak bisa meng-cover kerugian tersebut. Inilah mengapa rekening giro tidak secara langsung terkait dengan resiko usaha bank.

Yang menjadi masalah sekarang adalah bagaimana bank mampu menjaga kepentingan kedua deposan tersebut, baik bagi deposan giro maupun deposan investasi agar mereka tetap memiliki kepercayaan terhadap bank. Ini pula alasan yang mendasari manajemen bank untuk mengasuransikan dana deposa, termasuk rekening giro. ${ }^{31}$ Para deposan, terutama deposan investasi harus

30Baberapa ayat al Qur'an yang memerintahkan agar kita hidup hemat dan tidak berlebih, yaitu hidup secara moderat, adalah QS. al-An'âm (6): 141, QS. al-A'râf (7): 31, dan QS. al-Furqân (25): 67.

31Chapra dan Khan, Regulation and Supervision of Islamic Banks, Jeddah: Islamic Research and Training Institute, Occasional Paper Series no. 3, 2001), hlm. 101. 
Fahrur Ulum

dijaga dari adanya resiko pasar, kecurangan dan kesalahan manajemen dalam kontrak mudlârabah.

Perlu diperhatikan pula tentang komposisi kepemilikan saham, di mana hal itu harus dilakukan dengan mempertimbangkan keadilan dan persaudaraan, pemerataan distribusi pendapatan dan kekayaan serta unsur-unsur yang terdapat dalam maqâsid al-syarî'ah. Singkatnya, kepemilikan saham harus di-split. Jika tidak demikian, maka akan menimbulkan vested interest untuk memiliki saham secara dominan sehingga ia dapat mengendalikan kebijakan perbankan. Hal ini akan mendorong terciptanya perlindungan hukum atas kepentingan para pemegang saham minoritas dan deviden yang akan mereka dapatkan. Jika hal ini dapat terlaksana, maka nilai saham di pasaran bisa relatif lebih tinggi. 32

Secara singkat dapat disimpulkan bahwa bank syari'ah harus memiliki sikap disiplin yang kuat dalam melakukan investasi dan pengelolaan keuangan lainnya. Dengan sikap disiplin ini diharapkan mampu mereduksi persoalan-persoalan keuangan sebagaimana yang dihadapi oleh lembaga perbankan internasional. Namun karena kecilnya skala usaha dan dominasi pembiayaan berbasis jual beli, maka bank syari'ah sampai saat ini masih belum mampu menerapkan sikap disiplin ini.

\section{Pilar-pilar Pendukung Good Corporate Governance}

Beberapa sarana pendukung corporate governance, antara lain, adalah: Pertama, sistem kontrol internal yang efektif. Kontrol internal diperlukan untuk memastikan pengawasan manajemen dan meningkatkan budaya yang sehat dalam lembaga perbankan. Hal tersebut sangat dibutuhkan untuk mengakui dan menilai resiko, mendeteksi permasalahan dalam lembaga dan untuk mengoreksi kelemahan internal. Karena itulah Basel Committee33 dan pengawas perbankan di seluruh dunia menfokuskan perhatiannya pada pentingnya sistem kontrol internal ini. Untuk mendukung hal tersebut, dewan direksi dan manajemen secara bersama-sama harus

32Alexander Dydk, "Ownership Structure, Legal Protections and Corporate Governance": sdyck@hbs.edu (diakses 22 N ovember 2010)

33 Basel Committee on Banking Supervision, Framework of Internal Control System in Ban king O rganization: www.bis.org (diakses 22 N ovember 2010). 
menunjukkan integritas untuk menciptakan budaya yang memungkinkan semua pihak bisa memahami dan melaksanakan tanggung jawab masing-masing secara jujur dan efisien.

Sistem kontrol internal tersebut tidak mungkin bisa berjalan dengan baik tanpa adanya jalur komunikasi yang efektif dan ketersediaan informasi secara berkala. Karena itulah sisten kontrol internal harus dimonitor dengan basis ukuran tertentu untuk memastikan kepatuhan pada aturan dan prosedur, persetujuan dan otorisasi, limit pembiayaan, verifikasi dan rekonsiliasi.

Demikianlah, dengan sistem kontrol internal diharapkan beberapa resiko segera dikenali. Selanjutnya harus ada pemisahan pihak yang mengidentifikasi resiko dengan pihak yang mengelola dan mengontrol resiko.

Kedua, manajemen resiko. Sudah lazim bahwa bisnis perbankan -termasuk perbankan syari'ah- memiliki leverage yang tinggi. ${ }^{34} \mathrm{Hal}$ ini menuntut bank untuk mengembangkan sebuah sistem yang bisa membantu proses identifikasi, pengukuran, monitoring, dan kontrol secara tepat serta mampu meningkatkan efektifitas kerja manajemen.

Penerapan manajemen resiko yang tepat perlu difasilitasi dengan adanya pemisahan antara banking book activity dengan trading book activity. ${ }^{35}$ Trading book activity berhubungan dengan upaya diversifikasi portofolio dengan memperhatikan unsur resiko yang melekat pada banking book activity, serta berusaha mendapatkan

\footnotetext{
34Ketika tingkat return on equity (ROE) tergantung dari nilai aset, maka menjadi tendensi alamiah di sebagian bank untuk memiliki tingkat leverage setinggi mungkin, yaitu dengan meningkatkan volume simpanan secara terus menerus dan mengurangi porsi modal internal. Kalau sudah dalam posisi seperti ini, kerugian yang kecil saja atas asset cukup untuk menguras modal dan membuat bank menjadi kolaps. Efek domino dari peristiwa ini adalah ketika satu bank kolaps, maka mengakibatkan ketidakstabilan sistematis dalam sistem pembayaran, apalagi jika bank mengalami kerugian yang besar. Pembahasan yang lebih jelas silahkan baca Thariqullah Khan dan Habib A hmed, Risk M anagement: A $n$ A nalysis of Issues in Islamic F in ancial Industry, (Jeddah: Islamic Research and Training Institute, Occasional Paper Series N o 5, 2001), hlm. 45-51.

35 Chapra, Corporate Governance, hlm. 74.
} 
Fahrur Ulum

tambahan pendapatan melalai perdagangan surat-surat berharga, melakukan pengelolaaan dana investasi dan reksadana. ${ }^{36}$

Karena saat ini semakin tidak stabil harga komoditas, saham dan valuta asing, mengharuskan bank untuk memiliki kecukupan modal dan tingkat kesehatan bank yang baik. Sementara itu bagi bank, khususnya bank syari'ah, karakteristik resiko yang harus dikelola setidaknya antara lain resiko kredit, resiko likuiditas, dan resiko operasional.

Bank syari'ah menghadapi resiko kredit seperti layaknya bank konvensional, namun masih memiliki resiko tambahan, yaitu resiko yang berkaitan dengan profit and loss sharing. Karena itu dewan direksi bank syari'ah harus mampu menciptakan budaya resiko kredit yang wajar dalam operasional bank dengan membuat kesepakatan bersama dan me-review strategi yang digunakan bank secara periodik. Selain itu mereka harus mampu menentukan kriteria kualitas kredit yang bisa membantu menjelaskan kualitas nasabah, tujuan dan struktur kredit, sumber pengembalian kredit, historisitas pembayaran nasabah, kemampuan bayar kredit berjalan dan menentukan term and condition kredit nasabah. Demikian juga mereka harus mampu membuat prosedur yang tepat dalam melakukan amandemen dan perluasan kredit serta menciptakan informasi yang tepat untuk operasional manajemen, memepertimbangkan potensi perubahan kondisi perekonomian makro serta membangun sistem akses resiko kredit bank yang independen. ${ }^{37}$

Selain resiko kredit, bank juga menghadapi resiko likuiditas. Resiko likuiditas muncul ketika terjadi penurunan yang tidak diharapkan atas cash flow bersih yang dimiliki oleh bank, sementara itu pihak bank tidak mampu mendapatkan sumber dana dengan biaya yang wajar dan sesuai dengan ketentuan syarî'ah.

36Pada perbankan konvensional trading book berkaitan dengan perdagangan berbasis suku bunga, valuta asing dan perdagangan komoditas. Semua itu merupakan transaksii derivatif. Dalam perbankan syari'ah semua transaksi tersebut tidak diperkenankan. Oleh karena itu manajemen resiko dalam perbankan syari'ah mempunyai karakteristik yang berbeda dengan perbankan konvensional.

37Lebih jelas lihat Basel Committee on Banking Supervision, Principles for the $M$ anagemen of Credit R isk: www.bis.org (diakses 22 November 2010). 
Oleh karena itu, bank harus mempunyai manajemen likuiditas yang efektif, antara lain; pihak bank tidak hanya bergantung pada sejumlah deposan besar. Selanjutnya jangka waktu pembiayaan dan investasi harus ditentukan dengan time frame yang berbeda ketika membutuhkan cash flow untuk operasional harian telah tercukupi. Sistem asuransi simpanan dperlukan karena diharapkan bisa membantu bank ketika terjadi shock dalam kegiatan ekonomi serta meminimalisir terjadinya penarikan dana secara tiba-tiba. Pihak bank juga harus menyiapkan contingency plan untuk menopang usaha. Dan yang terakhir pihak manajemen likuiditas bank harus mampu meyakinkan senior management untuk melakukan monitoring dan kontrol terhadap kebutuhan likuiditas.

Penting pula untuk diperhatikan adalah resiko operasional. Resiko ini muncul karena lemahnya sistem kontrol internal dan corporate governance. Kelemahan tersebut akan menciptakan kerugian finansial yang disebabkan adanya error, self-dealing, penyelewengan, atau gagalnya pemenuhan kebutuhan secara tepat waktu dan efisien.

Resiko operasional juga bisa ditimbulkan oleh adanya kepentingan pihak bank yang melakukan kompromi dengan berbagai cara, misalnya oleh pihak dealer, para officer pembiayaan, atau staf lain yang mempunyai otoritas untuk mengambil bisnis dalam kaitannya dengan perbankan. Resiko operasional juga bisa disebabkan oleh kegagalan teknologi, menurunnya reputasi bank atau ketidakpatuhan terhadap standar regulasi.

Untuk memastikan bahwa bank telah melakukan usaha pengelolaan resiko operasional, maka pihak pengawas bank harus melakukan evaluasi terhadap strategi bank secara independen. Selanjutnya harus dipastikan pula bahwa bank telah memiliki sistem yang efektif untuk melakukan identifikasi, pengukuran, monitoring, dan control atas resiko operasional.

Ketiga, transparansi. Transparansi merupakan faktor penting bagi semua pelaku pasar. Transparansi merupakan kegiatan menyampaikan segala informasi yang dapat dipercaya dan tepat waktu kepada publik. Basel Committee menekankan keakuratan informasi perbankan meliputi enam subyek, yaitu; kinerja keuangan, posisi keuangan, strategi manajemen dan kontrol resiko, eksposur resiko, kebijakan akuntansi serta dasar manajemen bisnis dan 
Fahrur Ulum

informasi corporate governance.38 Untuk semakin memastikan efektifitas dan manajemen resiko yang aman, maka perlu sekali dukungan dari audit eksternal, termasuk pemurnian dan audit syari'ahnya.

Keempat, sistem akuntansi dan audit. Standar akuntansi yang tepat39 sangat dibutuhkan untuk mewujudkan transparansi bank sehingga mampu meningkatkan disiplin pasar dan meminimalkan kegagalan bank. Pihak pengawas bank harus memastikan bahwa laporan keuangan yang dipublikasikan oleh pihak bank secara fair telah merefleksikan kehati-hatian dan ukuran yang realistis tentang asset, liabilitas, moral transaksi derivatif, komitmen of balance sheet, serta keuntungan atau kerugian yang diderita oleh bank sehingga para user dapat mengetahui kondisi bank secara tepat. 40

Dari sisi audit, bank bisa menggunakan eksternal audit selain internal audit. Audit sangat diperlukan untuk memastikan bahwa laporan keuangan bank telah disajikan secara profesional dan sesuai dengan standar laporan keuangan. Selain itu, harus pula dipastikan bahwa keuntungan atau kerugian yang diungkapkan dalam laporan keuangan benar-benar merefleksikan kondisi bank sebenarnya, serta memastikan bahwa profit yang dihasilkan bukan dari usaha haram.

\section{Penutup}

Meskipun perbankan syari'ah telah berkembang pesat dalam tiga dekade terakhir ini, namun dari sisi aset, modal dan pengaruhnya masih relatif kecil. Oleh karena itu, dibutuhkan beberapa ukuran yang bisa mendukung perkembangannya, misalnya disiplin pasar, integritas moral bagi pengguna dan bagi lembaga jasa

38Basel Committee on Banking Supervision, Framew ork of In ternal Control System, hlm. 17-25.

39Standar akuntansi yang tepat biasanya meliputi aspek jumlah, format dan ukuran. Oleh karena itu Basel Committee mensyaratkan informasi yang jelas yang tertuang dalam laporan keuangan tahunan dan mencakup empat hal pokok, yaitu kebijakan dan praktek akuntansi, managemen resiko kredit, eksposur kredit, dan kualitas kredit. Lebih lengkapnya baca Basel Committee on Banking Supervision, B est P ractice of $C$ redit R isk D isclosure: www.bis.org (diakses 22 N ovember 2010).

40 Lihat Basel Committee on Banking Supervision, Core Principles: www.bis.org (diakses $22 \mathrm{~N}$ ovember 2010). 
keuangan, dukungan lingkungan sosio politik melalui penegakan hukum dan pengawasan lembaga yang adil.

Karena karakter bank syari'ah yang menekankan pada konsep berbagi resiko (risk sharing), maka corporate governance menjadi sangat urgen bagi perbankan syari'ah. Oleh karena itu, sangat penting bagi direksi dan senior manajemen untuk lebih efektif lagi dalam kinerja dan tanggung jawabnya. Demikian juga sarana pendukung corporate governance harus lebih disempurnakan, misalnya adanya kontrol internal, manajemen resiko, transparansi, akuntansi dan disklosur pembiayaan, pemurnian dan audit syari'ah, regulasi serta pengawasan yang prudent. Efektifitas pelaksanaan corporate governance menjadi tantangan tersendiri bagi terciptanya perbankan syari'ah yang unggul dan sekaligus menjadi tantangan profesionalitas stakeholder-nya. W allâh a'lam bi al-Shawâb.

\section{D aftar Pustaka}

Alchian, Armen. "Uncertainty, Evolution and Economic Theory", Journal of Political Economy, edisi 58 (1950)

Basel Committee on Banking Supervision, Core Principles of Banking Supervision: www.bis.org (diakses 22 November 2010).

Framework of Internal Control System in Banking Organization, www.bis.org (diakses 22 N ovember 2010).

Best Practice of Credit Risk Disclosure, September 2000: www.bis.org, diakses 22 November 2010.

Principles for the $M$ anagemen of Credit Risk: www.bis.org (diakses 22 N ovember 2010).

Chapra, M. Umer dan A hmed, Habib, Corporate Governance Lembaga Keuangan Syari'ah. Bumi A ksara: Jakarta, 2008.

Dyck, Alexander, Ownership Structure, Legal Protections and Corporate Governance: sdyck@hbs.edu (diakses 22 November 2010).

Iqbal, Munawar, Thariqullah Khan dan Ahmed, Aushuf,. Challenges Facing Islamic Banking. Jeddah: IRTI. 1998

Iwai, Katsuhito, "The Corporate Personality Controversy and Comparative Corporate Governance" dalam F. Cafaggi, A. 
F ahrur Ulum

Nicita and V. Pagano, Legal O rderings and Economic Institutions. London: Routledge, 2001.

Jenson, $M$ dan Meckling, "Theory of Firm: Managerial Behavior, Agency Cost and Ownership Structure", Journal of Financial E con omics, Nomor III (1976).

Keynes, John Maynard. Collected Writings of John M aynard Keynes. London: MacMillan for the Royal Economic Society, 1972.

Khaldun, Abd al-Rahmân Ibn, M uqaddimah. Kairo: Al-Maktabah alTijâriyyah al-Kubra, tt.

Khan, Thariqullah dan A hmed, Habib. Risk M anagement: An A nalysis of I ssues in Islamic Financial Industry. Jeddah: IRTI. 2001.

Mace, Myles. Directors: Myth and Reality. Boston: Harvard Business School Press, 1986.

North, Douglas and Wiengsat, Barry. "Chapter Ideology and The Free Rider, The Evolution of Institution Geverning Public Choice in the 17th Century England". Journal of Economic History, Vol 49 (1989)

Porta, La, Lopez de Salinas, A Shleifer dan R.W. Vinshy. Investor Protection; Origins, Consequences, Reform. Harvard: Harvard University Press, 2000.

Prentice, David. "Some Aspect of Corporate Governance Debate". Dalam Contemporary Issues in Corporate Governance. Oxford: Clarendon Press, 2001.

Prowse, Stephen, Corporate Governance; Emerging Issues and Lesson for E ast A sia: www.worldbank.org/ html/ extdr/ pos981.

Roepke, Wilhelm, "Ordred Anarchy”, in Lawrence Stepplevich, The Capital ist R eader. New York: N ew Rochelle A rlington, 1977.

Schleifer dan Vishny, "A Survey of Corporate Governance", Journal of Finance (June, 1977). 